\title{
Exploring the Training Needs of French Teachers in Relation to the Teaching of French as a Foreign Language in Greek Primary Schools
}

\author{
Iosif Fragoulis \\ As. Professor, School of Pedagogical and Technological Education \\ Tutor, Hellenic Open University, Patra, Greece \\ Tel: 30-2610-910-066 E-mail: sfaka@otenet.gr
}

Received: August 22, 2011 Accepted: September 22, 2011 Published: February 1, 2012

doi:10.5539/ies.v5n1p130

URL: http://dx.doi.org/10.5539/ies.v5n1p130

\begin{abstract}
Nowadays, the role of the school in the formation of students-future citizens with high educational level and specialized knowledge is undeniable. The introduction of the second foreign language from the first years of schooling differentiates the school curriculum and constitutes an effective preparation of the students for the future society (Kaga, 2002:66-71.Kaga, 2004).

The present study examines the training needs of the French language teachers in the context of the teaching of the French language in Primary Education.

More specifically, it examines the training needs of the teachers as far as the preparation and design of teaching, its organization, implementation and evaluation are concerned.

The results of the research show that there is a need for systematic training of French language teachers in relation to the design, the implementation and the evaluation of teaching interventions in Primary Schools.
\end{abstract}

Keywords: Training needs, French teachers, Teaching french, Greek primary schools

\section{Introduction}

Multilingualism constitutes nowadays one of the basic skills necessary for the successful and effective participation in the European knowledge society. In addition, the knowledge of foreign languages contributes to the participation of people in the society and the maintenance of social cohesion in the framework of the multicultural society (Zouva,2008:85, Kamarinou, 2008:97.Kamitsi, 2009:48).

The promotion of linguistic diversity constitutes one of the priorities for education in all the European Union countries. In the member states of the European Union the teaching of foreign languages needs to start from the early years of schooling so that students-future citizens have early access to the cultural richness of the European Union member states (Kaga, 2003).

\section{The Introduction of French as a Foreign Language in the Primary School}

The teaching of French as a foreign language in the primary school was first introduced in the school year 2005-2006 in 219 primary schools across Greece. In total, 3516 students received instruction of the French language (Kamitsi, 2009:39). The assigning of the schools in which French was going to be taught as a foreign language was based on the following ministerial decisions: a) $\Phi .52 / 480 / 71029 / \Gamma 1 / 18-7-2005$, and b) $\Phi .52 / 812 / 127372 / \Gamma 1 / 14-11-2005$. For the teaching of French only primary schools with 6 or more teachers were selected.

From school year 2006-2007 onwards, the teaching of French as a foreign language was expanded to the sixth class of all primary schools with six or more teachers. From the school year 2007-2008 the teaching of the French language was introduced to the fifth and the sixth class of all primary schools with six or more teachers for two hours per week (Kamitsi, 2009:40). For the teaching of French as a foreign language in primary schools, a new analytical curriculum was developed, the philosophy of which is based on the following:

- the development of positive attitudes toward the French language and culture, so that students acquire motivation to learn the language 
- the sensitization and acquaintance of students with the linguistic codes of the French language as far as comprehension and production of oral and written speech is concerned, so that students develop a conscious familiarity with the language

- The connection of the language with experiential learning, so that students gradually acquire the skills necessary for using their linguistic knowledge in real life communicative contexts (Kaga, 2008:11).

\section{The Concept of Training Needs}

In the international as well as the Greek bibliography, the term "training need" is defined on the basis of two different approaches: a) as the distance between an existing situation and some desired pattern, in other words, as the deficit in skills that are considered necessary for the successful implementation of a specific work, or in the equal participation in dimensions of the social life, and b) as the interest and motivation for participation in the educational process, which may be a result of subjective estimations (Xasapis, 2000. Karalis, 2005). The training needs are defined as needs of individuals, institutions, social groups, a geographical area, or fields of the economy and the labour market (Vergidis, 2008). Training needs are further divided into conscious and non-conscious ones.

According to the functionalist approach, training needs emerge when the individuals realise that they lack knowledge necessary for the successful implementation of their job, which are the result of scientific and social developments. Even if the degree of realisation of the needs within a given population is high, the expression of the training needs is not always clear. In many instances and for a number of reasons (e.g. avoidance of negative judgement, or erroneous judgement of those involved in relation to acquisition of knowledge), the training needs are expressed indirectly or are alluded to. As a result, their examination becomes a multifaceted process with many meanings, which takes into account the needs that are directly expressed, for example conscious and explicit needs, but also needs that need to be examined in order to emerge and be identified, such as latent needs. There are three types of needs: a) conscious and specific, b) conscious and not specific, c) latent and not specific (Vergidis \& Karalis, 2008).

\section{Research Methodology}

\subsection{Aim of the Research}

The aim of the research is to examine the training needs of French teachers in relation to the teaching of French as a foreign language in primary schools in Greece.

\subsection{Research Questions}

The extend to which the demographic characteristics of French teachers (age, occupational status, teaching experience in the teaching of French as a foreign language, teaching experience in primary education) impact on their training needs in relation to the preparation-planning of their teaching intervention.

The extend to which the demographic characteristics of French teachers (age, occupational status, teaching experience in the teaching of French as a foreign language, teaching experience in primary education) impact on their training needs in relation to the implementation of teaching.

The extend to which the demographic characteristics of French teachers (age, occupational status, teaching experience in the teaching of French as a foreign language, teaching experience in primary education) impact on their training needs in relation to the educational techniques and the means of teaching.

The extend to which the demographic characteristics of teachers of French (age, occupational status, teaching experience in the teaching of French as a foreign language, teaching experience in primary education) impact on their training needs in relation to the evaluation of the learning process.

\subsection{Research Population-sample-research Limitations}

The research sample was 54 teachers of French, from a total of 65 French teachers in primary schools in the prefecture of Achaia. Sample selection was made on the basis of random sampling from the total population of the French teachers in primary schools in the prefecture of Achaia (Dimitropoulos, 2001:52-54). The research was conducted in the specific sample of French teachers, and therefore the research findings are not necessarily generalisable for the whole country.

\subsection{Data Collection}

We used a questionnaire to collect data, since it allows the collection of a large number of data in a short time. Data collection would be extremely time consuming if we had used another method of data collection, due to the large number of the sample and also in relation to time constraints (Dimitropoulos, 2001:210). Using closed questions allowed us to collect the necessary quantitative data for conducting the research (Cohen \& Manion, 1997:140-141. 
Kyriazi, 1999:127-131).

4.5 Statistical Analysis

The analysis of the questionnaires was made using the statistical package SPSS V.17, which is widely used in social sciences. Using the statistical package SPSS V.17 we conducted the analysis of the questions in the questionnaires.

\section{Research Findings}

\subsection{Demographic Characteristics}

We found the following in relation to the demographic characteristics of the research sample.

In relation to gender

All the respondents who participated in the research and completed the questionnaires $(\mathrm{N}=54)$ were females.

In relation to age

From the research sample, 14 (22.6\%) were between $24-35$ years old, 30 (48.4\%) were between $36-45$ years old, while $10(16.1 \%)$ were between $46-55$ years old.

Table 1 . Sample distribution by age

In relation to occupational status

Thirty two $(51.6 \%)$ of the respondents were teachers who had a permanent position, while $22(35.5 \%)$ were substitute teachers (teachers who teach on a part time basis).

In relation to teaching experience in the teaching of French as a foreign language

Twenty one (33.9\%) had teaching experience between 1-10 years, 25 respondents (40.3\%) has teaching experience between 11-20 years, while 8 French teachers (212.9\%) responded that they had teaching experience between 21-30 years.

In relation to teaching experience in primary education

Twenty five respondents (46.4\%) reported having teaching experience between 1-2 years, 8 respondents (14.8\%) between 3-4 years, while 21 French teachers $(38.8 \%)$ responded that they had teaching experience in primary education between 5-6 years.

Table 2. Teaching experience in primary education

\subsection{Teacher Attitudes in Relation to Preparation-planning of the Teaching Intervention}

As far as responds to the question "Would you like to train in issues regarding the correct expression of the aims of your teaching intervention?" are concerned, the research findings showed the following: 33 respondents (53.2\%) answered "very much", 14 respondents (22.6\%) answered "a lot", while 7 respondents $(11.3 \%)$ responded that they would be "enough" willing to do so. The two-variable analysis and the check of $x^{2}$ criterion showed significant statistical differences $(a<0,05)$ among the subjects' answers regarding their age $(p=0,01)$, their job status $(p=0,00)$ and the years of teaching experience in primary education $(\mathrm{p}=0,01)$.

In relation to the answers to the question "Would you like to train in issues regarding the improvement of your students' communicative skills?", the research findings revealed that 16 respondents $(29.7 \%)$ answered "very much", 19 respondents (35.1\%) answered "a lot", 15 French teachers $(27.8 \%)$ answered that they would be "enough" willing, while 4 respondents (7.4\%) answered "very little-not at all". The two-variable analysis and the check of $x^{2}$ criterion showed significant statistical differences $(\mathrm{a}<0.05)$ among the subjects' answers regarding their age $(\mathrm{p}=0,01)$, their job status $(\mathrm{p}=0,00)$ and the years of teaching experience in primary education $\quad(p=0,01)$.

Table 3. Improvement of students' communicative skills

In relation to answers to the question "Would you like to train in issues related to the improvement of multicultural ethos and ethos of communication between speakers of different languages?" the research data showed the following: Thirteen respondents (21\%) answered "very much", 33 answered "a lot", while 8 respondents (12.9\%) answered "enough". The two-variable analysis and the check of $x^{2}$ criterion showed significant statistical differences $(a<0.05)$ among the subjects' answers regarding their age $(\mathrm{p}=0.02)$, their job status $(\mathrm{p}=0.01)$ and the years of teaching experience in primary education $(\mathrm{p}=0.00)$.

In relation to the answers to the question "Would you like to train in issues related to the sensitization of the students regarding cultural difference?" the research data showed the following: Eleven respondents $(17.7 \%)$ answered "very much", $33(53.2 \%)$ answered "a lot", while 10 respondents (16.1\%) answered "enough". The two-variable analysis and the check of $x^{2}$ criterion showed significant statistical differences $(\mathrm{a}<0.05)$ among the subjects' answers 
regarding their job status $(\mathrm{p}=0.00)$ and the years of teaching experience in the primary education $(\mathrm{p}=0.02)$.

\subsection{Teacher Attitudes about Teaching}

When asked "Would you like to train in issues about effective ways to motivate your students to learn?" 12 French teachers (19.4\%) answered "very much", 27 (43.5) answered "a lot", while 15 teachers (24.2\%) answered that they would be "enough" interested. The two-variable analysis and the check of $x^{2}$ criterion showed significant statistical differences $(\mathrm{a}<0.05)$ among the subjects' answers regarding their age $(\mathrm{p}=0.00)$, their job status $(\mathrm{p}=0.01)$ and the years of teaching experience in primary education $(\mathrm{p}=0.00)$.

As regards answers to the question "Would you like to train in issues related to the adaptation of the content of teaching to the flow of the learning process?" the research data revealed the following: Nineteen respondents (35.2\%) answered "very much", 22 respondents (40.7\%) "a lot", 9 respondents $(16.7 \%)$ answered "enough", while 4 respondents (7.4\%) answered "very little-not at all". The two-variable analysis and the check of $x^{2}$ criterion showed significant statistical differences $(\mathrm{a}<0.05)$ among the subjects' answers regarding their job status $(\mathrm{p}=0.00)$ and the years of teaching experience in primary education $(\mathrm{p}=0.01)$.

Table 4. Adaptation of teaching to the flow of the learning process

As regards answers to the question "Would you like to train in issues related to the adaptation of the teaching content to your students' needs?" the research data revealed the following: Seventeen respondents (27.4\%) answered "very much", 20 respondents $(32.3 \%)$ "a lot", while 17 respondents $(27.4 \%)$ answered "enough". The two-variable analysis and the check of $x^{2}$ criterion showed significant statistical differences $(a<0.05)$ among the subjects' answers regarding their job status $(\mathrm{p}=0.01)$ and the years of teaching experience in primary education $(\mathrm{p}=0.01)$.

As regards answers to the question "Would you like to train in issues related to effective use of time in the context of the teaching intervention?" the research data revealed the following: Fourteen respondents $(26.0 \%)$ answered "very much", 23 respondents $(42.5 \%)$ "a lot", while 17 respondents $(21.5 \%)$ answered "enough". The two-variable analysis and the check of $x^{2}$ criterion showed significant statistical differences $(\mathrm{a}<0.05)$ among the subjects' answers regarding their job status $(\mathrm{p}=0.01)$ and the years of teaching experience in primary education $(\mathrm{p}=0.00)$.

\subsection{Teacher Attitudes about Teaching Techniques and Means of Teaching}

As regards answers to the question "Would you like to train in issues related to exploitation of effective teaching methods?" the research data revealed the following: Twenty nine respondents $(53.7 \%)$ answered "very much", 14 respondents (26\%) "a lot", 8 respondents (14.8\%) answered "enough", while 3 respondents $(5.5 \%)$ answered "a little-not at all". The two-variable analysis and the check of $x^{2}$ criterion showed significant statistical differences $(a<0.05)$ among the subjects' answers regarding their age $(\mathrm{p}=0.01)$, their job status $(\mathrm{p}=0.02)$ and the years of teaching experience in primary education $(\mathrm{p}=0.01)$.

Table 5. Exploitation of effective teaching methods

As regards answers to the question "Would you like to train in issues related the use of collaborative teaching methods?" the research data revealed the following: Seventeen respondents $(27.4 \%)$ answered "very much", 27 respondents (43.5\%) "a lot", while 10 respondents $(16.1 \%)$ answered "enough". The two-variable analysis and the check of $x^{2}$ criterion showed significant statistical differences $(\mathrm{a}<0.05)$ among the subjects' answers regarding their job status $(\mathrm{p}=0.01)$ and the years of teaching experience in primary education $(\mathrm{p}=0.00)$.

As far as answers to the question "Would you like to train in issues related the selection of appropriate audiovisual aids?" are concerned, the research data revealed the following: Twenty one respondents $(33.9 \%)$ answered "very much", 14 respondents (22.6\%) answered "a lot", while 19 respondents (30.6\%) answered "enough". The two-variable analysis and the check of $x^{2}$ criterion showed significant statistical differences $(\mathrm{a}<0.05)$ among the subjects' answers regarding their age $(\mathrm{p}=0.00)$, their job status $(\mathrm{p}=0.01)$ and the years of teaching experience in primary education $(\mathrm{p}=0.00)$.

In relation to answers to the question "Would you like to train in issues related the effective use of audiovisual aids?" the research data revealed the following: Twenty five respondents (40.3\%) answered "very much", 16 respondents (25.8\%) answered "a lot", while 13 respondents (21\%) answered "enough". The two-variable analysis and the check of $x^{2}$ criterion showed significant statistical differences $(\mathrm{a}<0.05)$ among the subjects' answers regarding their job status $(\mathrm{p}=0.00)$ and the years of teaching experience in primary education $(\mathrm{p}=0.01)$.

\subsection{Teacher Attitudes about the Evaluation of the Learning Process}

As regards answers to the question "Would you like to train in issues related the use of appropriate methods of student assessment?" the research data revealed the following: Thirty one respondents (50\%) answered "very much", 
16 respondents $(25.8 \%)$ answered "a lot", while 7 respondents $(11.3 \%)$ answered "enough". The two-variable analysis and the check of $\mathrm{x}^{2}$ criterion showed significant statistical differences $(\mathrm{a}<0.05)$ among the subjects' answers regarding their age $(\mathrm{p}=0.00)$, their job status $(\mathrm{p}=0.01)$ and the years of teaching experience in primary education $(\mathrm{p}=0,00)$.

As regards answers to the question "Would you like to train in issues related the self-evaluation of your teaching intervention?", the research data revealed the following: Fifteen respondents $(27.8 \%)$ answered "very much", 14 respondents (26\%) answered "a lot", 21 respondents (38.8\%) answered "enough", while 4 respondents (7.4\%) answered "very little-not at all". The two-variable analysis and the check of $\mathrm{x}^{2}$ criterion showed significant statistical differences $(\mathrm{a}<0.05)$ among the subjects' answers regarding their age $(\mathrm{p}=0.00)$, their job status $(\mathrm{p}=0.01)$ and the years of teaching experience in primary education $(\mathrm{p}=0.00)$.

Table 6. Self-evaluation of the teaching intervention

As regards answers to the question "Would you like to train in the use of appropriate techniques for student evaluation?", the research data revealed the following: Thirteen respondents $(21 \%)$ answered "very much", 32 respondents $(51.6 \%)$ answered "a lot", while 9 respondents $(14.5 \%)$ answered "enough". The two-variable analysis and the check of $x^{2}$ criterion showed significant statistical differences $(a<0.05)$ among the subjects' answers regarding their job status $(\mathrm{p}=0.00)$ and the years of teaching experience in the primary education $(\mathrm{p}=0.01)$.

As regards answers to the question "Would you like to train in issues related the critical evaluation of your teaching planning?", the research data revealed the following: Fifteen respondents (24.2\%) answered "very much", 30 respondents $(48.4 \%)$ answered "a lot", while 9 respondents $(14.5 \%)$ answered "enough". The two-variable analysis and the check of $x^{2}$ criterion showed significant statistical differences $(a<0,05)$ among the subjects' answers regarding their age $(\mathrm{p}=0.00)$, their job status $(\mathrm{p}=0.00)$ and the years of teaching experience in the primary education $(\mathrm{p}=0.00)$.

As regards answers to the question "Would you like to train in issues related the use of the recognition of strong and weak aspects of your teaching intervention?" the research data revealed the following: twenty five respondents (40.3\%) answered "very much", 17 respondents (27.4\%) answered "a lot", while 12 respondents (19.4\%) answered "enough". The two-variable analysis and the check of $x 2$ criterion showed significant statistical differences $(a<0.05)$ among the subjects' answers regarding their job status $(\mathrm{p}=0.00)$ and the years of teaching experience in the primary education $(\mathrm{p}=0.01)$.

\section{Conclusions}

The research shows that a big percentage of French teachers wish to train in issues related to the preparation and planning of their teaching intervention. This wish is greater in younger teachers aged 25-35 years, in substitute teachers, as well as in teachers with 1-2 years of teaching experience in primary education.

Research data also reveal that a great number of French teachers wish to be systematically trained in issues about the implementation of teaching of the French as a foreign language in primary schools. This trend is greater in teachers aged 36-45 years, in substitute teachers, as well as in teachers with 1-2 years teaching experience in primary education.

The research also shows that a great percentage of French teachers want to train about issues related to the use of effective techniques and means of teaching in the framework of their teaching intervention. This is more frequently expressed by teachers aged 36-45 years, as well as in teachers with 5-6 years teaching experience in primary education.

Based on the research data, we also found that a great number of French teachers want to be systematically trained about the assessment of the learning process. Their demographic characteristics, and most specifically, their age, occupational status, and their teaching experience impact on their wish to be trained about the evaluation of their teaching intervention on primary school. This wish is more frequently expressed by teachers aged $24-35$, by substitute teachers, and by teachers with 3-4 years teaching experience in primary education.

\section{Suggestions}

For the successful implementation of the training of French teachers in the teaching of French as a foreign language in the primary school we suggest:

- The systematic examination of the teachers' training needs

- The adaptation of the contents of the training to the specific characteristics and wishes of the teachers'

- The exploitation of the methodological framework of adult education in the teachers training 
- The exploitation of active training techniques in the teachers' training

- A combination of theoretical knowledge and practice

- The exploitation of flexible training techniques, such as the blended method, which entails a combination of live and distance learning

\section{References}

Cohen, L., \& Manion, L. (1994). Methodology of Educational Research. Athens: Metaixmio. (In Greek)

Dimitropoulos, E. (2001). Introduction to the Methodology of Scientific Research. Athens: Ellin. (In Greek)

Kaga, E. (2002). Linguistic and cultural polymorphism. Cross-curricular approaches to foreign languages. Review of Educational Issues, 7 (1), 66-71

Kaga, E. (2003). European Language Portfolio. Athens: Eiffel.

Kaga, E. (2004). Portfolio of languages: novel practical approaches of multilingual literacy. In Ministry of Education (Ed.), Language and literacy in the new millennium. Athens: Greek letters. (In Greek)

Kaga, E. (2008). The teaching/learning of the French Language in Primary Education. Managing the Analytical Program of Studies in the classroom. In Ministry of Education (Ed.), Book of Abstracts for the French Language (pp.11-16). Athens: Ministry of Education. (In Greek)

Kamarinou, E. (2008). Multicultural teaching. In Ministry of Education (Ed.), Book of Abstracts for the French Language (pp.97-99). Athens: Ministry of Education. (In Greek)

Kamitsi, E. (2009). Teachers' opinions about the introduction of the French as a Foreign Language in the Primary School. Patras: University of Patras. (In Greek)

Karalis, A. (2005). Designing programs of adult education. In Hellenic Open University (Ed.), Designing, Management and Evaluation of Adult education Programs (pp. 15-66). Patras: Hellenic Open University. (In Greek)

Kyriazi, N. (2005). The Sociological Research. A critical review of methods and techniques. Athens: Greek letters. (In Greek)

Ministerial Decisions. (2005). Ф.52/480/71029/Г1/18-7-2005. (In Greek)

Ministerial Decisions. (2005). Ф.52/812/127372/Г1/14-11-2005. (In Greek)

Vergidis, D., \& Karalis, A. (2008). Introduction to Adult Education, Patras: Greek Open University. (In Greek)

Xasapis, D. (2000). Design, organisation, implementation, and evaluation of Occupational Training Programs. Methodological Principles and Quality Criteria. Athens: Metaixmio. (In Greek)

Zouva, E. (2002). The multicultural teaching of the French language in the Primary School through the educational software «multimedia builder». In Ministry of Education (Ed.), Book of Abstracts for the French Language (pp.85-89). Athens: Ministry of Education. (In Greek)

Table 1. Sample distribution by age

\begin{tabular}{|l|l|l|}
\hline $24-35$ years & 14 & $22,6 \%$ \\
\hline $36-45$ years & 30 & $48,4 \%$ \\
\hline $46-55$ years & 10 & $16,1 \%$ \\
\hline Total & $\mathbf{5 4}$ & $\mathbf{1 0 0} \%$ \\
\hline
\end{tabular}

Table 2. Teaching experience in primary education

\begin{tabular}{|l|c|c|}
\hline 1-2 years & 25 & $46,4 \%$ \\
\hline 3-4 years & 8 & $14,8 \%$ \\
\hline 5-6 years & 21 & $38,8 \%$ \\
\hline Total & $\mathbf{5 4}$ & $\mathbf{1 0 0 \%}$ \\
\hline
\end{tabular}


Table 3. Improvement of students' communicative skills

\begin{tabular}{|l|c|c|}
\hline Very much & 16 & $29,7 \%$ \\
\hline A lot & 19 & $35,1 \%$ \\
\hline Enough & 15 & $27,8 \%$ \\
\hline Very little-not at all & 4 & $7,4 \%$ \\
\hline Total & $\mathbf{5 4}$ & $\mathbf{1 0 0 \%}$ \\
\hline
\end{tabular}

Table 4. Adaptation of teaching to the flow of the learning process

\begin{tabular}{|l|c|c|}
\hline Very much & 19 & $35,2 \%$ \\
\hline A lot & 22 & $40,7 \%$ \\
\hline Enough & 9 & $16,7 \%$ \\
\hline Very little-not at all & 4 & $7,4 \%$ \\
\hline Total & $\mathbf{5 4}$ & $\mathbf{1 0 0 \%}$ \\
\hline
\end{tabular}

Table 5. Exploitation of effective teaching methods

\begin{tabular}{|l|c|c|}
\hline Very much & 29 & $53,7 \%$ \\
\hline A lot & 14 & $26,0 \%$ \\
\hline Enough & 8 & $14,8 \%$ \\
\hline A little-not at all & 3 & $5,5 \%$ \\
\hline Total & $\mathbf{5 4}$ & $\mathbf{1 0 0} \%$ \\
\hline
\end{tabular}

Table 6. Self-evaluation of the teaching intervention

\begin{tabular}{|l|l|c|}
\hline Very much & 15 & $27,8 \%$ \\
\hline A lot & 14 & $26,0 \%$ \\
\hline Enough & 21 & $38,8 \%$ \\
\hline Very little-not at all & 4 & $7,4 \%$ \\
\hline Total & $\mathbf{5 4}$ & $\mathbf{1 0 0} \%$ \\
\hline
\end{tabular}

